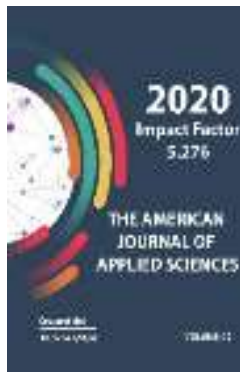

Journal Website: http://usajournalshub.c om/index,php/tajas

Copyright: Original content from this work may be used under the terms of the creative commons attributes 4.0 licence.

\section{Reflection Of The Nature And Community Relation In Place Names}

\author{
Kuchkar Mahkamovich Khakimov \\ Professor, Department Of Methods Of Teaching Geography, Jizzakh State Pedagogical \\ Institute, Uzbekistan \\ Meliboy Normatovich Kamolov \\ Candidate Of Economic Sciences, Senior Lecturer, Department Of Geography Teaching \\ Methods, Jizzakh State Pedagogical Institute, Uzbekistan
}

\title{
ABSTRACT
}

The study of the territorial aspects of the nature and society reflected in the names of places is important not only for the science of toponymy, but also for the sciences of geography. In this article toponymics which occupies an intermediate position in the system of geographical sciences and it's study was the subject the reflection of nature and community relation in geographic names was investigated using concrete examples.

\section{KEYWORDS}

Toponymic, toponymy, geographic names, area, nature, society and economic-social factors, ethnonym, oronym, gidronym, zoonym, fitonym.

\section{INTRODUCTION}

Mankind has not yet fully understood the mysteries of the land in which it lives and works. Because it is not always easy to understand the nature of objective events in the natural environment, they often required special attention from people. Therefore, in everyday life, when communicating with the surrounding world, people pay attention to the distinguishing features of natural objects and name them in order to distinguish them from each other.

According to experts, in the process of naming, the specific features of the geographical 
object, that is a geographical location, natural conditions, historical and ethnocultural features, economic activity played an important role. If the names given initially were often random, then the official names that reflect the real event were multiplied later. Apparently, any geographical name is a product of understanding the world, the desire to study it more deeply has led to the emergence of new geographical names. In other words, the development of human society and the expansion of people's territorial imagination have led to an increase in the number and complexity of names.

\section{THE MAIN RESULTS AND FINDINGS}

Consequently, names that are a product of social necessity reflect the daily life, ethnic composition, language history, national and spiritual values of the people in a particular region, as well as the geographical environment that surrounds them. For this reason, for centuries, experts have paid special attention to place names and their etymology in order to discover the laws of nature, to learn the various mysteries.

Indeed, place names are important not only as an integral part of national values, but also because they reflect changes in nature and society. Therefore, place names can serve as an important source in the study of the relationship between nature and society and the natural and economic-social changes that have taken place during historical development in comparison with the present.

\section{GOALS AND OBJECTIVES OF THE WORK}

The main purpose of the research is to reflect the interaction and influence of nature and society in place names and to study the regional aspects of changes that occur during their period of evolution. During the research it is planned to perform the following tasks:

1) Analysis of toponymic aspects of the relationship between nature and society;

2) Study the reflection of natural geographical factors in place names;

3) Study of place names formed on the basis of socio-economic factors;

4) Promotion of advanced scientific ideas in the field.

\section{THE MAIN PART}

When we talk about the relationship and interaction of society with nature, we mean the part of nature that interacts with society, i.e. the geographical environment. Because, "the geographical environment is the part of nature where human society exists, where all human life and productive activity takes place. Man gets everything he needs - water, air, food, housing and other building materials, raw materials for the whole industry from the geographical environment "[1. Volume 2 b.623].

First and foremost, humanity seeks to assimilate more of the part of nature that surrounds society and has a direct impact on people's lives in order to meet their needs. As a result, there is a constant connection and interaction between society and nature, that is, the natural environment, which, in turn, leads to an expansion of the composition and size of the geographical environment. Now, the rapid development of science and technology, the rapid growth of the population, the continuous use of nature by man have raised the interaction between society and nature to a qualitatively new level.

Experts write that in the Middle Ages, great attention was paid to natural conditions, and even believed that people's character, behavior, lifestyle, development of the state, etc. are determined by the natural conditions 
of the country, its geographical location. For example, our great compatriot Abu Rayhan Beruni wrote that "the differences in the structure, image, nature and morals of people are due not only to the diversity of their genealogies, but also to the diversity of soil, water, air and land" [2. -b.33].

It is known that in the early stages of the development of society, people mainly used the natural resources necessary for life. Consequently, people observed their surroundings and named them in order to distinguish geographical objects from each other. Initially, natural objects were given simple, plain and random names out of necessity, but later, as social consciousness developed, the number of concepts increased and the place names became more complex.

Names representing the natural features of geographical objects were more common in the early stages of society, and later the number of names formed on the basis of socioeconomic factors also gradually increased as a result of the increasing influence of society on nature. This was due to the development of human society, the increase of daily needs, the assimilation of new territories and components of nature [9].

Hence, the more humanity assimilates nature, the greater the need to name new geographical objects, which leads to an increase in the number and importance of place names. Consequently, the close relationship between nature and society can also be seen in historically formed geographical names, in a particular region, on the basis of certain laws that represent their integrity and are a vivid external expression of nature. Simply put, place names are a linguistic expression of the relationship between nature and society.

Geographical names that arose out of social need often reflected nature and natural conditions. Because nature has given people the opportunity to meet their daily needs and enjoy comfortable natural conditions. For example, there are many place names in areas with favorable natural conditions for living and widely used in agriculture, which reflect the various components of nature, such as landforms, water bodies, plant, animal species and their specific features.

Experts write that place names play a special role in educating the population in the spirit of nature protection and efficient use of its resources. Indeed, geographical names have to some extent served to protect nature and the environment throughout all eras. Therefore, in recent years, toponymic research has focused more on the ecological function of names.

Sometimes, the given name caused the place to be carefully preserved, to be considered sacred, to be deified. Such names reflected the spiritual world of the local people, with the help of which the land, water, air, flora and fauna of the region, in a word, all the components of nature were preserved. The name of the place helped to keep the area clean and tidy and the people to live in peace and tranquility. As a result, efforts were made to use natural resources wisely and economically, without harming the components of the surrounding nature.

In our holy religion, it is also stated that Allah created the earth as a suitable place for human life, and that everything in nature serves the interests of man. In turn, everyone will have to treat nature wisely and take care of it. In recent years, many plant and animal species have completely disappeared or their numbers have declined sharply as a result of increasing manmade impacts on nature, environmental changes, and declining forest-occupied areas.

It is known that the Turkic peoples have long considered land and water sacred. In particular, water played an important role in their lives and economic activities. According to ethnographer G.P Snesarev, in the distant 
past, the present-day Amudarya was called Vakhsh by the Khorezmians. The ancient Khorezmians, who believed in Zoroastrianism, used to sacrifice cattle to the river with good intentions every spring, in honor of the water goddess Vakhshvara and the goddess of fertility Anakhita, "let there be water, let there be fruit, let there be plenty."

The people, using the method of legal protection, using place names, tried to preserve the biological diversity of Mother Nature, preserve the environment, and in a sense achieved their goals. Such geographical names not only clearly defined the location, but also contributed to the formation of a high ethno-ecological culture in the population.

Changes in nature and society have led to the emergence of new names in a particular region and in a specific historical context. At the same time, the increasing influence of society on nature, the exchange of historical periods, languages and peoples have laid the groundwork for changes in the geographical environment. The change in the geographical environment and the expansion of the scale led to the emergence of many new geographical features and their naming. In recent years, as a result of climate change and the impact of human economic activities, some animal and plant species are declining or disappearing altogether. It is important to identify and restore their distribution areas.

Using toponymic data, it is possible to accurately determine the distribution areas of certain species of fauna and flora. In such cases, geographical names come to the rescue. For example, Azerbaijani anthropologists R.M.Yuzbashev and E.B.Nuriev used the place names to determine the distribution areas of gazelles. Geographical names such as Jayronli, Jayronkul, Jayronbulak indicate that the gazelle was more widespread in the republic in the past [4].
Everything in a society (material and spiritual wealth, creation of necessary conditions for human life, etc.) takes place in the course of a certain activity. Human activity and social relations between people form the core of society. Society does not exist without material production, and it is in production that society's connection with nature is manifested [1. Volume 3, -b.543].

It is known that flora and fauna are natural resources. From ancient times man has tried to study them, to determine their area, to use them in moderation. For example, in the toponymy of Andijan, Tashkent, Jizzakh regions there are place names such as Betaga, Betagali, Betagalisoy. Betaga is a small grass that the locals named after knowing that it is a food plant for livestock.

Zahiriddin Muhammad Babur gave a wonderful description of the beta plant. "In Andijan, this herb is called an idol, and the Vajhi ribbon was not known, it was known in the provinces. This grass is called a bush so that it grows into a bush "[5. -b.198]. This plant really grows in clusters. As Babur said, betagan is especially fond of yearlings, the beetle that walks on betagali pasture is well fattened, and kumizi is fat and pleasant.

Place names also provide a lot of information for socio-economic geography, which studies the relationship between nature and society, as different aspects of the people's way of life are reflected in geographical names. For example, the names of settlements can be considered more important than the names of other geographical objects, because they reflect the political, economic and social life of the country. With the help of oykonim it is possible to clarify such issues as the ancient forms of economic management of the population, the leading industries, extracted minerals, caravan routes of the past, advanced types of handicrafts, the distribution area of peoples. 
Various socio-economic aspects of people's lives are also reflected in geographical names. It is known that our people have long been engaged in various professions. Although some of the professions of the past have disappeared, but they are still preserved in the composition of place names. Names from different regions of Uzbekistan, such as Pichokchi, Oqchi, Sandiqchi, Temirchi, Mahsidoz, Parchabof, Misgaron, Naqqashan, Taqachi, Degrez, Zargarlik, Qassoblik, Sovungarlik, indicate the professions of the local people [6].

The name of the city of Ahangaron in the Tashkent region means blacksmiths and is a reference to the past occupation of the local population. Similarly, the main occupation of the residents of Sozangaron makhalla (neighbourhood) in Samarkand was the production of needles, juvaldiz, bigiz. If we look at the place names of the republic, we can see that pottery, along with other professions, is much more developed. Village and makhalla (neighbourhood) names such as Kulolon, Kulolchi, Kulollik, Tandirchi, Kosagaron, Tavoqchi are a clear example of this.

The place names contain a number of geographical names related to the weaving profession, which indicate that the history of the weaving profession dates back to ancient times. In the names of such settlements as Bakhmalbof, Gilambof, Buyrabof, Parchabof, the "traces" of the local people's weaving profession have been preserved. Sewing was also one of the most popular industries among our people. For example, one of the neighborhood of Margilan was called Yormadoz in ancient times. One of the most widely used types of embroidery in embroidery, the people of the neighborhood have been engaged in this work in the past.

The names of neighborhood such as Mahsidozon in Bukhara, Dozanda in Chust, and Zardozon in Samarkand are also attributed to people. Professionals who make leather from it are called tanners. There were many tanneries in Samarkand, Bukhara, Tashkent, Fergana Valley and Khorezm. They are made of sheep, goat, cattle and camel skins. The name of this profession was the basis for Konchilar in Tashkent, Konchilik in Margilan, Charmgaron in Chust, and Charmgar in Samarkand.

Geographical names also include place names related to agricultural production. The emergence of such place names is often associated with the natural conditions of the area. It is named according to which type of farming there is a good opportunity to develop in that area. For example, in places where there are favorable conditions for growing cotton, Pakhtakor, Pakhtachi, Oqoltin, in areas with good grain yields, such as Gallakor, Bugdoychi, Gallaorol, Lalmikor, Sholikor.

In addition, the toponymy of the republic includes many other toponyms, such as Komirchi, Nosgar, Sangtarosh, Buyrachi, Ohakchi, Egarchi, Toshkesar, which reflect the various professions of the local people in the past and present. At the same time, place names have also emerged on the basis of devices that produce a variety of products that are necessary for the daily needs of the local people. The names of these devices were later changed to the names of settlements, such as Sariosiyo, Galaosiyo, Koshtegirmon, Tegirmonovul, Koshjuvoz, Objuvoz.

The market, which is a place of trade, has also long played a major role in the way of life of the local people. Therefore, in places such names as Bozorjoy, Yangibazar, Kohnabozor, Sarbozor or Bedabozor, Egarbozor, Yogbozor, Khodabozor, Tavuqbozor, Buyrabozor, which specialize in selling a certain product, appeared. Sometimes, the names of settlements such as Friday, Wednesday, Thursday, and Monday, which also gave names to villages depending on the day of the market, were created in this way. 
In general, the various components of nature, the historical, social and political events that have taken place in the life of society over the centuries, the occupations of the population are sealed in place names. Modern society, modern civilization, any connection between people and countries cannot be imagined without geographical names. Today, the growth of economy and culture, the development of international relations further increase the role and importance of place names in society.

\section{CONCLUSION}

Analyzing the toponymic aspects of the relationship between nature and society, the following conclusions can be made:

-geographical names reflect the changes that have taken place in a particular historical context and in society with nature;

-natural geographical factors played a key role in the formation of most place names;

-toponyms reflect the political, economic, social changes that took place during the development of society;

-the emergence of geographical names is closely connected with the life of the society, the language and ethnic origin of the peoples living or living in that area;

-the name of a place is a linguistic expression of the connection between nature and society.

\section{REFERENCES}

1. National Encyclopedia of Uzbekistan. Volumes 1-12, -T .: 2000 -2007.

2. Soliev A.S. Fundamentals of economic and political geography. -T., 2003. -158 p.

3. Murzaev E.M. Geography in nazvaniyax. M ; 1979.

4. Memedov N.G. Toponymy. -Baku, 2007. 408 pages.

5. Bobur Zahiriddin Muhammad. Boburnoma. - T .: 1960. -368 p.
6. Hakimov Q.M. Toponymy.-T .: 2016.-368 p.

7. Hakimov Q.M., Mirakmalov M.T. Toponymy. -T .: 2020. -355 p.

8. Hasanov H. Selected works. -T .: 2019. -335 p.

9. Khakimov K.M. Geographical names. JCR.2020; 7 (6): 121-124.

10. Gudalov, M., \& Imamova, D. (2020). Development Of Ecoturism In AydarArnasay Lakes System And Its Surroundings. The American Journal of Applied sciences, 2(10), 150-153.

11. Mirkomil, G., Gulshoda, J., \& Ilyos, J. (2020). Ways To Develop Ecotourism In The Molguzar Mountains. The American Journal of Applied sciences, 2(11), 1-5.

12. Mirkomil, G., \& Bakhtiyor, Z. (2020). METHODS OF STUDYING THE LANDSCAPES AROUND THE AYDARARNASAY LAKE SYSTEM. International Engineering Journal For Research \& Development, 5(7), 5-5.

13. Mirkomil, G., Bakhtiyor, Z., \& Dilfuza, I. (2020). Predicting Changes In Landscapes Around The Aydar-Arnasay Lake System. The American Journal of Engineering and Technology, 2(10), 6-12.

14. Mirkomil, G., \& Matluba, G. (2020). WAYS TO DEVELOP MODERN ECOTOURISM IN THE ZAAMIN BASIN. International Engineering Journal For Research \& Development, 5(7), 5-5.

15. Gudalov, M. (2019). Foundation of AydarArnasay lakes system and their effects on the environmental landscape. Nature and Science, 17(11).

16. Kholikulov, A. B. (2019). Bukhara emirate's farming in the XIX-XX centuries (in the case of Kashkadarya oasis stables). ISJ Theoretical \& Applied Science, 04 (72), 546549.

17. Rasuljanovna, I. N., \& Rakhmonqulovich, K. N. (2020). Trade Relations Between Ancient Bacteria And China On The II-I BC. The American Journal of Social Science and Education Innovations, 2(07), 47-51. 
18. Karimov, N. R. (2020). A True Successor of Great Central Asian Scholars. Journal «Bulletin Social-Economic and Humanitarian Research,(7), 62-69.

19. Kariev, A., \& Aminov, H. (2020). New information about Imam al-Zarnūjī and his work "Ta'līm al-Muta'allim". Solid State Technology, 63(6), 2372-2387. 